\title{
The volatility of institutional arrangements that influence development: The case of Bram Fischer International Airport in South Africa
}

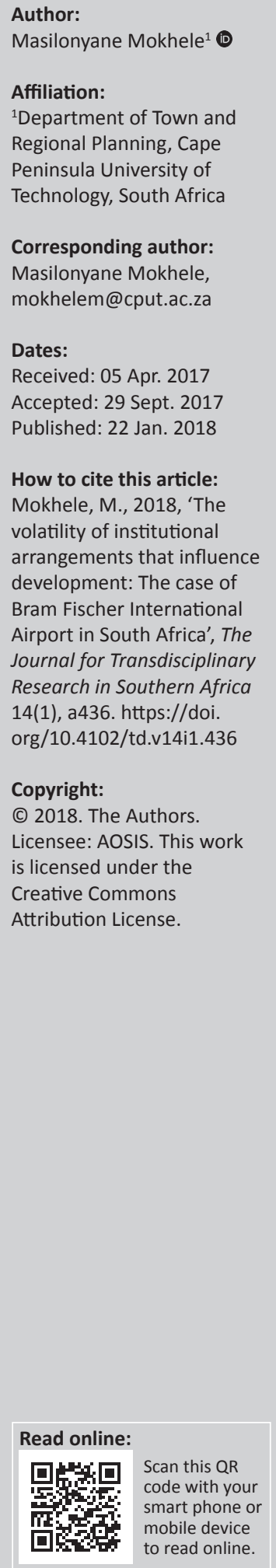

Author

Affiliation

${ }^{1}$ Department of Town and Peninsula University of

Corresponding author: Masilonyane Mokhele, mokhelem@cput.ac.za

Dates: Accepted: 29 Sept. 2017

How to cite this article: Mokhele, M., 2018, 'The volatility of institutional arrangements that influence Bram Fischer International Airport in South Africa', The 14(1), a436. https://doi.

\section{Copyright:}

(C) 2018. The Authors. is licensed under the Creative Commons Attribution License.

\begin{abstract}
Hailed as the best integration of the airport and urban development, models of airport-led development are used worldwide to promote the ideal land-use mix and spatial form of airport environs. Despite the growing popularity of airport-led development, there is a lack of literature investigating how the institutional arrangements of African cities can facilitate or inhibit the implementation of such development. Using Bram Fischer International Airport in South Africa as a case study, this article describes the nature and evolution of the institutional arrangements that influence development on and around airports. Informed by the conceptual framework of historical institutionalism, the findings unveiled two contradictory phases in the evolution of institutional arrangements at the case studied: firstly, a period of harmony where all actors worked towards a common goal and, secondly, a period characterised by the absence of cooperation among stakeholders.
\end{abstract}

\section{Introduction}

Praised by proponents as the epitome of economically and physically integrated strategies of the airport and urban development (Schlaack 2010), a multitude of planning models are used to promote the ideal land-use mix and spatial form of airport environs (for a thorough overview, see Freestone \& Baker 2011). Becoming bandwagons across the world, the models of airport-led development are dominated by the notions of airport city and aerotropolis. Airport city is associated with the growth of economic activities around airports because of their dependence upon airports (see Conway 1993; Kasarda 2009; Walker \& Stevens 2008), and as more firms are pulled towards airport cities, the urban form of aerotropolis emerges, consisting of developments that could extend up to $30 \mathrm{~km}$ from airports (e.g. Kasarda 2009; Kasarda \& Lindsay 2011).

Citing several examples, Mokhele (2017) notes that like in other parts of the world, the models of airport-led development are gaining wide currency in South Africa. However, despite the growing popularity of the so-called airport-led development, there is a lack of literature investigating how the institutional arrangements of African landscapes might facilitate or inhibit the implementation of such development. ${ }^{1}$ Using Bram Fischer International Airport in South Africa as a case study, the aim of this article was to describe the nature, evolution and volatility of institutional arrangements that influence development on and around airports. Transcending the disciplines of human geography, town and regional planning, sociology and political science, the elementary argument advanced herein is that the roles and interdependencies of institutions operating within African cities need to be considered carefully in the planning and implementation of development on airport environs. It should be noted from the onset that the article does not advance proposals on how the institutional processes should be organised, or how they should have been organised, within the case studied.

The article is organised as follows. Following this introduction, the next section provides a brief overview of literature on the institutional arrangements that influence development on and around airports. The 'Conceptual framework and research methods' section outlines the conceptual frame of reference and research methods that the article is based upon. The penultimate section presents the findings on the nature and evolution of institutional arrangements at Bram Fischer International Airport and its surroundings. The last section concludes the article.

.Although the term 'institution' has a long history dating back to around 1725 (and used in philosophy, sociology, politics and geography) there is no consensus regarding its definition (Hodgson 2006). The most widely used definition is that of North (1990, 1996), who defines institutions as the formal rules, the informal constraints and the enforcement characteristics of each. According to Aoyama, Murphy and Hanson (2011), through the lens of economic geography, institutions can be organisations, laws and regulations, whose purpose is to coordinate economic activities by promoting or deterring developments. 


\section{A brief overview of literature}

Various stakeholders form affiliations to either support or oppose the development of airport environs (Van Wijk 2007). The current section highlights selected studies on the institutional arrangements pertaining to the development of the environs of Frankfurt (Germany), Schiphol (The Netherlands) and Orly (France) international airports. Developments on and around Frankfurt International Airport are influenced by stakeholders with varying interests and responsibilities wherein planning is particularly focused on facilitating infrastructure investments so as to promote development (Van Wijk 2008). Van Wijk (2008) notes that the socioeconomic impact of Frankfurt Airport extends to the states of Hesse, Bavaria and Rhineland-Palatinate. However, given that the airport is located within the boundary of the City of Frankfurt, the local government is, in addition to Hesse, the main actor that facilitates airport planning and development on and around the airport (Van Wijk 2007).

With that background, it is important to highlight the roles of different actors in the institutional arrangements that influence development on and around Frankfurt Airport. Van Wijk (2007) notes that the state of Hesse is solely responsible for the airport's airside (aviation related) expansion processes, while the City of Frankfurt is responsible for the real estate and infrastructure development, through operating as a facilitator for developers and other commercial players. According to Van Wijk (2008), another crucial actor is the regional transport authority of Rhein Main Verkehrsverbund (RMV), a publicly financed but independently functioning body comprising a number of local and regional governments as shareholders. In the airport's development, RMV's involvement is in terms of the plans for the regional transport initiatives that connect the airport with the surrounding areas (Van Wijk 2008).

As regards Amsterdam Schiphol region in the Netherlands (i.e. a functional region encompassing the airport), Van Boxtel and Huys (2005) note that decision-making regarding the development of the airport has been a controversial process since the 1960s. However, consensus could at times be reached, which, in 1991, culminated in the accepted plan for the development of the airport environs. Galvin (2010) asserts that development plan resulted in a substantial growth of the region, accommodating activities ranging from logistics to mixed use projects. According to Van Wijk (2008), the province of North Holland plays a mediating and coordinating role between the local and national governments, and between private and public interests. It also supervises local land-use plans to ensure that they align with the regional land-use plan. In the Schiphol regional plan, encompassing areas around the airport, the province sets land-use and zoning regulations, including location approval based on airportrelatedness criteria. Zoning is implemented to protect the airport and its surroundings from traffic congestion wherein it is required that the closer the land is to the airport, the more airport-related the proposed development should be (Van Wijk 2008).
Galvin (2010) adds that the province (North Holland) is part of two forums where it acts as a coordinating body. Firstly, there is an administration forum known as the Bestuursforum Schiphol (BFS), which is the urban planning actors' platform in the airport region. The BFS is chaired by the province, with the municipalities of Amsterdam and Haarlemmermeer as its members. Secondly, on a larger scale, there exists an administrative coordination group, Bestuurljke Schiphol, which includes neighbouring regions and municipalities that are interested in the airport's aviation development.

Galvin (2010) notes that the public-private actors' system is coordinated by two bodies during the development implementation phase: firstly, the Schiphol Area Development Company (SADC) coordinates public guidelines and private interests to achieve coherent development processes. Functioning as an economic development agency, SADC is also authorised to develop land. According to Van Wijk (2008), SADC is, however, not in charge of real estate development. Private real estate developers undertake the real estate functions. The second coordinating body, Amsterdam Airport Area, which is a public-private association with members ranging from municipalities to port authorities, handles the marketing and communication duties of a larger defined airport area (Galvin 2010).

In France, Galvin (2010) notes that in 2007, development in the Orly Airport area became so important that it was classified as a national project. National projects are located in areas with relatively big development potential and are carried out by the French land planning ministry. As a result of this arrangement, in areas characterised by the high concentration of businesses, local planning actors were replaced with a state agency, the Establissement Public d'Amenagement (EPA). Policymaking and land planning are therefore almost completely the responsibility of the state wherein prefectures (representing the state at provincial level) are the only bodies mandated to issue construction licences and grant project authorisations within the national projects. Local stakeholders participate in the development implementation phase through an economic development agency, which is the strategic coordination body that brings together the institutional and market actors, and accordingly assists companies to find locations to operate from (Galvin 2010).

The brief overview of literature above reflects that there are diverse ways in which stakeholders engage in the development of airports and surroundings. It serves as a backdrop to the description of the institutional arrangements pertaining to the case studied.

\section{Conceptual framework and research methods \\ Conceptual framework}

In its endeavour to describe the nature, evolution and volatility of institutional arrangements that influence airportcentric developments, the article is befitting the institutional 
turn in human geography. According to Martin (2000), that turn is based upon the premise that the economic landscape cannot be fully understood without considering the institutions on which economic activity depends. The assumption is that although institutions cannot be the sole cause of particular geographical patterns of development, they can enable or constrain development. In human geography, three conceptual approaches can typically be distinguished, which provide different interpretations of institutions, namely historical institutionalism, rational choice institutionalism and sociological institutionalism (Martin 2000). These are overviewed below, followed by an indication of the approach that was adopted in the Bram Fischer International Airport study.

According to Hall and Taylor (1996), historical institutionalists define institutions as the formal or informal procedures embedded in the organisational structure of the economy. Historical institutionalists particularly analyse the evolution of institutional structures over time and attempt to understand how that evolution impacts the space economy. In that analysis, institutions are seen as the products of historically situated interactions, conflicts and negotiations among actors (Martin 2000). In the lens of historical institutionalism, the state is no longer seen as a neutral body facilitating and reconciling competing interests, but it is understood as a set of institutions capable of structuring and influencing the character and outcomes of conflicts (Hall \& Taylor 1996).

In the rational choice perspective, the focus is, among others, on how far and in what way institutions serve to increase efficiency (Martin 2000). Using behavioural assumptions, rational choice institutionalists posit that the actors have a fixed set of preferences or tastes; while operating in a strategic manner, they attempt to maximise the attainment of those preferences. In that context, an actor's behaviour is likely to be driven, instead of by impersonal historical factors, by a strategic reasoning and calculation, which is, in turn, influenced by that actor's expectations about how others are likely to behave as well. Institutions are particularly useful in structuring such interactions among actors (Hall \& Taylor 1996).

In the sociological model, institutions are seen as culturally influenced routines, networks of trust, obligation and cooperation. As such, institutions provide frameworks of meaning through which economic identities and actions are legitimised in society. Sociological institutionalists see institutional evolution as arising out of collective processes of interpretation, and emphasis is put on the ways in which existing institutions structure the range of institutional change (Martin 2000). Unlike the rational choice institutionalists, sociological institutionalists argue that certain institutional practices are adopted not because they enhance efficiency but because they augment the social legitimacy of the actors concerned (Hall \& Taylor 1996).

Although the three approaches described above are closely related, the historical institutionalism is befitting the analyses that attempt to understand how the institutional structures evolved over time and how the development of the Bram Fischer airport-centric development was accordingly impacted by that evolution and the associated volatility.

\section{Research methods}

This article is based on a case study approach centred on the Bram Fischer International Airport, which is located approximately $8.5 \mathrm{~km}$ east of the Bloemfontein CBD, in the jurisdiction of Mangaung metropolitan municipality, Free State province. Owned and managed by the Airports Company South Africa (ACSA), Bram Fischer International Airport was opened in 1961, known then as the JBM Hertzog Airport, named after the former Prime Minister of the Union of South Africa. ${ }^{2}$ The airport is located along the planned N8 corridor and is regarded by the authorities as one of the important nodes along the corridor.

Bram Fischer International Airport was selected as a case study because the researcher was part of the institutional arrangements affecting the development on this airport from around 2008 to 2014. This allowed for first-hand experience of the institutional arrangements and a good platform for tracing their nature, evolution and volatility. Because of the time dimension, the study can be regarded as longitudinal research, with investigations spanning over a 7-year period. In contrast to cross-sectional studies, longitudinal research is advantageous because it permits observations of the same phenomena over an extended period (Babbie 2001; Leedy \& Ormrod 2010). Given that it allows for an analysis of the evolution of institutional arrangements over time, longitudinal research is particularly well suited to the conceptual framework of historical institutionalism.

In social research, there are two main non-mutually exclusive techniques of data collection: quantitative and qualitative approaches. This article is exclusively informed by field research as a component of qualitative research (e.g. see Babbie 2001; Neuman 2000). It is argued that the ethnographic method used here is richer in comparison to other methods such as qualitative interviewing and getting the insights of people who were involved in or are knowledgeable of the phenomena investigated. Such methods do not always yield the accurate story, as the respondents would potentially provide answers that are perceived to be logical, instead of reflecting on exactly what happened. As participant observers, field researchers conduct case studies on groups of people for some length of time (Neuman 2000). The following were used as main sources of information in the field research conducted: meeting invites, observations at meetings and minutes of meetings held between the various actors. However, to avoid potential ethical issues (see below), those records are not appended to this article.

2.The airport was later renamed Bloemfontein International Airport and changed to the current name in 2012, named after one of the prominent anti-apartheid activist, the current name in 2012, named after one of the prominent anti-apartheid activist,
Abram 'Bram' Fischer. The paper consistently uses the name of Bram Fischer International Airport regardless of the timeframe under discussion. 


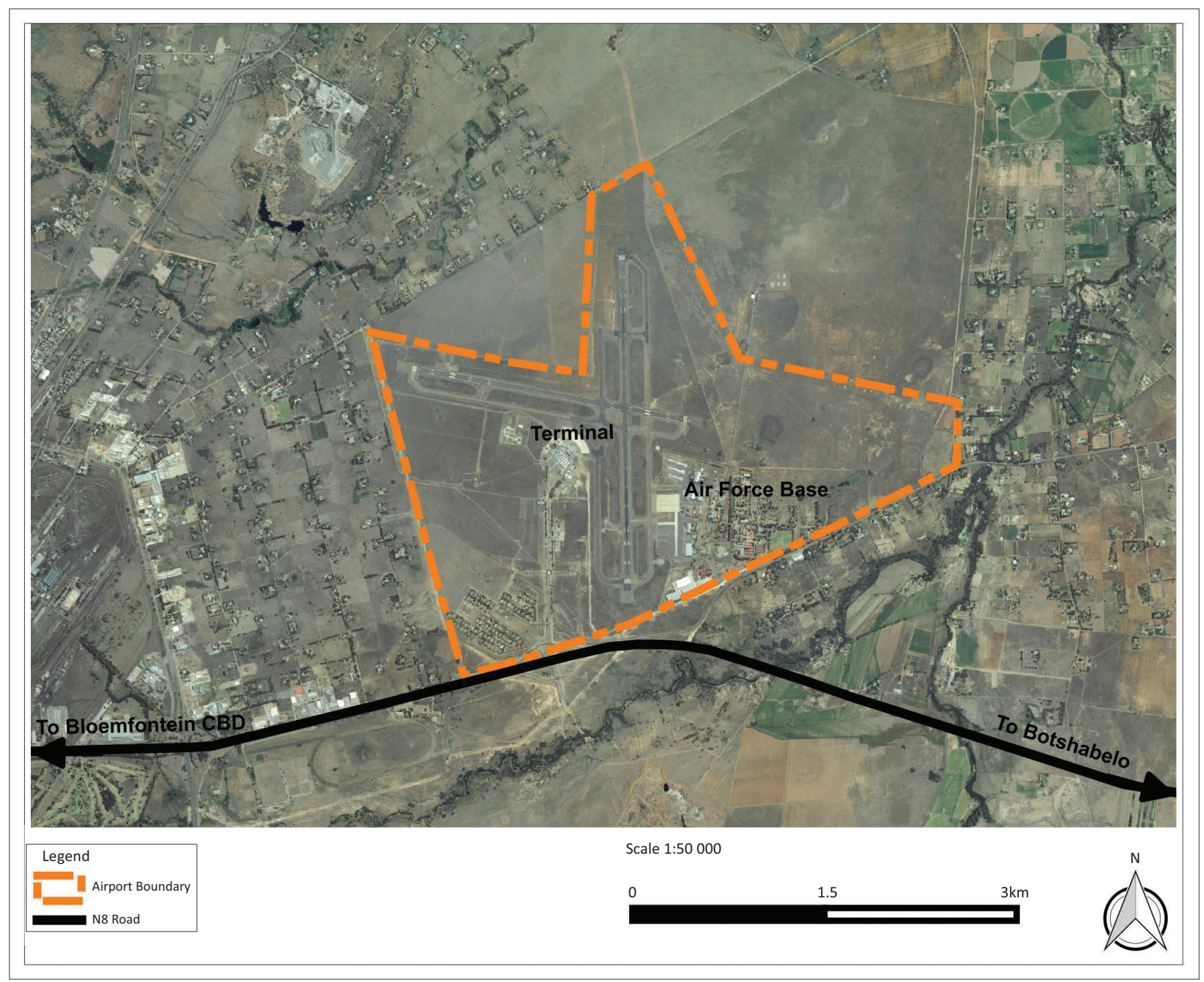

Source: Aerial photograph: Republic of South Africa, 2011

FIGURE 1: Location of Bram Fischer International Airport.

\section{Ethical considerations}

The researcher was involved in the institutional arrangements purely as a professional town and regional planner; the idea of documenting and analysing the evolution emerged as the institutional arrangements unfolded. In that light, the research might be questioned on the aspect of objectivity as the researcher might be seen to belong to a particular 'camp' and thus represent the views of that group. To circumvent the objectivity problems, the article focuses on the institutional structures rather than on the individuals that make up the structure. In other words, it describes the evolution of institutional arrangements without focusing on individual actors that are (or were) part of those arrangements. However, because of the aforementioned ethical concerns, the article has a typical weakness of prioritising institutional structures over human agency (see, for instance, Martin 2000). A conscious decision was taken that it is proper to leave the analysis of human agency in the hands of people who were not directly involved with the structures analysed.

\section{Findings and discussion}

Within the ambit of historical institutionalism, this section fulfils two objectives:

1. It provides a snapshot of the main actors with direct influence on the urban development of the Bram Fischer International Airport's premises.

2. It subsequently sketches the findings on the evolution of stakeholder arrangements within the case studied.

\section{Overview of the main actors}

During the timeframe of the study, three main stakeholders or actors had direct influence on the development of the Bram Fischer International Airport's premises: ACSA, the landowner and operator of the airport; Mangaung metropolitan municipality, the local authority; and the Free State provincial government. In order to put the subsequent findings and discussion in context, the mandates of these actors are summarised below. 
ACSA was established in 1993 with the authority to acquire, establish, develop, maintain, manage or operate principal airports in South Africa (RSA 1993). ACSA is majorly owned (74.6\%) by the South African government and is accountable to the Minister of Transport (ACSA 2014), and is thus legally classified as a state-owned company. The revenue of ACSA is derived from two principal sources. On the one hand, according to ACSA (2014), aeronautical revenue is obtained from aircraft landing, parking and passenger service fees. On the other hand, non-aeronautical revenue is derived from retailers on airport premises, car rental firms, advertising, car parking, property development and property leases on airport premises. To reflect its significance, non-aeronautical revenue contributed 36\% of ACSA's total revenue in 2013 (ACSA 2014); and to further enhance that revenue, ACSA promotes urban development on the airport premises through leases to the developers. It is also important to note that, long before the introduction of the models of airport-led development in South Africa, ACSA initiated programmes at its airports to unlock the development potential. ACSA-owned airports that have been the subject of such initiatives include OR Tambo, Cape Town, Bram Fischer, Kimberley, George, Upington, East London, and Port Elizabeth airports.

As prescribed in the country's constitution (RSA 1996), South African government consists of the national, provincial and local spheres. Of relevance to urban development generally, and specifically to the case study, Mangaung municipality (like other municipalities) has constitutional authority over the matters listed in Schedules $4 \mathrm{~B}$ and $5 \mathrm{~B}$ of the Constitution, including the power to administer those matters. Municipal powers intersect with provincial powers in two ways. Firstly, the provincial government has its own constitutional competencies identified in Schedules $4 \mathrm{~A}$ and $5 \mathrm{~A}$ of the Constitution, which include provincial planning, regional planning and development, and urban and rural development. Secondly, the provincial government has powers over the local government matters listed in Schedules $4 \mathrm{~B}$ and 5B. With that background, in the case of Bram Fischer International Airport, the decisions related to land-use applications were, at the time of the study, made at provincial government level, based on the recommendations of the Mangaung municipal council. ${ }^{3}$ Following the deliberations of the provincial Townships' Board, the member of the provincial executive council (MEC) for cooperative governance, traditional affairs and human settlements would ultimately proclaim positive decisions in the provincial gazette.

The background above, which includes particularly the two overlapping spheres of government, calls for a brief overview on the concept of state in so far as it relates to development. As noted by Aoyama et al. (2011), it is needless to say that operating in diverse political ideologies, economic institutions and statesociety relationships, states perform crucial roles in structuring economic development. Generally, in the development process, a state's intervention attempts to manipulate the timing, nature

3.This arrangement changed from around November 2015 with the establishment of the Mangaung Municipal Planning Tribunal (MPT). Some decisions on land-use applications are now made by municipal officials, while others are referred to the MPT. and location of development, thus influencing in one way or another the spatial distribution of economic activity (Leitner \& Sheppard 1989). In economic geography, three perspectives on the concept of state can be identified. The first view regards state as a force that intervenes to correct market failures and neutrally guide economic processes. That is in essence similar to liberal-pluralist perspectives wherein states are seen as autonomous from economic institutions and thus able to decide neutrally over questions of resource distribution and other state functions. The second perspective views the state as inseparable from capitalist systems and the geographical context where it is situated. That view is similar to Marxist perspectives, which dismiss the perspective that regards states as neutral, rather than seeing them as institutions whose actions are aimed at perpetuating capitalist accumulation. Thirdly, Neo-Weberian perspectives take a middle stand and believe that although the state is embedded in socioeconomic institutions, it can act autonomously in decision-making processes (Aoyama et al. 2011). Among the perspectives above, the Marxist perspective is arguably more aligned with the conceptual framework of historical institutionalism.

\section{Institutional arrangements at Bram Fischer International Airport}

The findings of institutional arrangements cover a 7-year timeframe, within which two main phases are distinguishable:

1. an initiation phase that commenced in earnest in 2008 to about 2012, characterised by cooperation among the different stakeholders

2. a second phase from around 2012 to 2014 , marked by a lack of a common goal and the absence of cooperation among the actors.

\section{Initiation and momentum of stakeholder engagements}

Initiatives to introduce urban development on the premises of the Bram Fischer International Airport began in 2007, when ACSA appointed a group of consultants to investigate the potential of unlocking the land for development. The preliminary screening process entailed, among others, confirmation of the land ownership, the boundaries of ACSA's landholdings, and checking that the property's title deed contained no conditions that would proscribe urban development. Subsequent to that process, the first formal stakeholder meeting was held on 07 April 2008 between ACSA, the consultants, Mangaung municipality (planning department) and the Free State provincial government (spatial planning division of the Department of Cooperative Governance, Traditional Affairs and Human Settlements) to explore a desirable process to be followed in the development of the Bram Fischer International Airport's premises. Although the idea of promoting urban development on airport premises was foreign within the municipality and provincial government, those actors were largely willing to listen and keen to assist. At the time, the immediate development needs were, among others, around the hospitality sector pertaining to the imminent 2010 FIFA 
soccer world cup. This was particularly critical because Bloemfontein was one of the host cities.

The stakeholders agreed on the process as follows: firstly, because development on the airport premises was only managed in terms of the title deed as the site was not part of any Town Planning Scheme (TPS), the property had to be incorporated into the Bloemfontein TPS (No. 1 of 1954) boundaries so as to allow urban development to occur. The decision to use Bloemfontein TPS instead of Bloemspruit TPS like some of the neighbouring properties was that the former would in future provide scope for the development of diverse activities. Secondly, subject to the incorporation into the Bloemfontein TPS, the property had to be rezoned to an appropriate zone that would permit urban development. In that respect, the stakeholders agreed that the property be rezoned to 'special use', which implied that, upon motivation and consideration by the authorities, the property could in essence accommodate any appropriate land use that is part of the Bloemfontein TPS. That flexibility was appreciated and agreed upon by the actors. An agreement included that at the time, the special use would include a hotel and also regularise the existing aviation and non-aviation land uses on the airport, including the terminal, car rental facilities, maintenance buildings and so on. The incorporation and rezoning applications were submitted to the authorities as agreed upon.

To explore and guide future activities on the premises of Bram Fischer International Airport, ACSA continued to formulate a spatial development framework with a multidisciplinary team comprising town planners, engineers (civil, traffic and electrical) and an environmentalist. On 15 May 2009, a meeting was convened between ACSA, the consultants, Mangaung municipality and the provincial government to apprise the authorities of the preliminary investigations towards a development framework, introduce the preferred hotelier for the proposed hotel, obtain feedback on the rezoning application process and to get guidance on the process to be followed to get the development framework approved.

Following the meeting of 15 May 2009, the approval for rezoning of the property to special use CXXI (in the form of gazette proclamation) was granted in November 2009. The hotel was subsequently constructed on the airport property in time for the 2010 FIFA soccer world cup and has since been operational.

Building upon the meeting of 15 May 2009, as well as other stakeholder interactions, in November 2010, ACSA presented and submitted the airport's development framework (final draft) to the Mangaung municipality and the Free State provincial government. The framework showed the longterm vision for development on the property and unpacked how the implementation would be phased. The municipality and provincial government endorsed the framework as a basis for guiding development on and around the airport. Officially, that decision was incorporated into the Integrated
Development Plan in the form of a clause that 'it is ... recommended that all land-use development in the Bloemfontein Airport area be conducted in context of the Bloemfontein Airport Development Framework' (Mangaung Municipality 2013:212).

In July 2011, the Free State Premier convened major landowners along the proposed N8 corridor to discuss their plans, requirements and anticipated timeframes so as to unblock the bottlenecks constraining development along the N8 Corridor. That high-level meeting, chaired by the Premier, was held on 13 July 2011 and, notably, ACSA's Chief Executive Officer and the Executive Mayor of the Mangaung municipality were in attendance. ACSA's consultant presented the airport's development framework and apprised the Premier of the intention to develop a hospital on the airport premises. The proposals were largely well received, albeit one of the senior municipal officials asked, 'why can't the hospital be developed across the road?' referring to municipal land located opposite the airport. As a culmination of the meeting, the Premier appointed a senior official to set up the N8 working group or forum with the mandate of integrating the planning initiatives of various stakeholders located along the proposed N8 Corridor, including ACSA.

The N8 forum was coordinated by a senior official from the provincial Department of Environment and Economic Development. Other participants included the various departments of Mangaung municipality (planning, engineering and transportation planning), the Free State Provincial Government, the Free State Development Corporation and Centlec (Mangaung municipality's entity mandated with the provision of electricity services), among others. The main workshops were held on 21-22 July 2011 and on 30 August 2011 at the Mangaung municipality wherein all the parties were granted an opportunity to present their plans, demands and expectations. ACSA's immediate needs at the time included the establishment of a hospital mentioned earlier. The process culminated in the compilation of the draft N8 Development Framework. Immediately after the conclusion of the N8 forum, in August 2011, ACSA submitted an application to the Free State Provincial Government and the Mangaung municipality for the amendment of the special use CXXI to incorporate a hospital, warehousing and business premises. The authorities considered that application speedily, and the approval was promulgated, within about 4 months, on 20 January 2012. The hospital subsequently opened its doors in early 2017.

\section{Institutional conflicts}

From around 2012, there was a major reconfiguration of the institutional arrangements, which started to reflect a lack of cooperation and resistance from one key stakeholder. On 28 October 2011, ACSA (in compliance with the processual agreement reached in 2008) had submitted an application to the Mangaung municipality and the Free State Provincial Government for the amendment of the special use CXXI to permit the establishment of a 3MW photovoltaic system (typically referred to as solar farm) on the airport premises. 
Given the apparent delay in processing that application, various attempts were made by the developer to meet with the municipality and avail any information that could be required for a decision to be made. Despite the South African Air Force having supported the proposal before, one of the additional pieces of information required by the municipality was a letter from the neighbouring Bloemspruit Air Force Base, located on the Bram Fischer International Airport premises, confirming that the proposed solar farm would not interfere with their operations. A final version of that letter was submitted to the municipality on 27 March 2013. Following various meetings and discussions between the developer and the Mangaung municipality, the municipality ultimately confirmed officially that they did not support the development of a solar farm on the airport premises. The confirmation was in a letter of recommendation (dated 30 August 2013) to be considered towards a final decision by the provincial government. It should be noted that, ironically, the municipality indicated that they supported the idea of a solar farm but not on the airport premises because the location was 'strategically unsuitable'. Accordingly, the developer (through the appointed town planning company) submitted a letter to the provincial government, appealing the recommendation of the Mangaung municipality and stating the merits of the solar farm proposal. It is important to note that, concurrently, the municipality had unveiled its plans in the media towards developing the area around Bram Fischer International Airport into an aerotropolis. Reflecting a dire breakdown in the institutional arrangements, ACSA were not informed of the municipal plans, while some of the municipal proposals even encroached onto ACSA's land. This breakdown marked an era of 'scramble for the airport' and 'scramble for development'. Interestingly, also in the media, the municipality revealed its intentions to construct a solar park next to the Bram Fischer International Airport (see Van Wyk 2013), definitely not referring to the proposal on the airport premises.

Following the letter of appeal above, the Mangaung municipality and the developer were summoned for an inspection in loco and to present their cases before the neutral committee, the Free State Land Advisory Board on 15 November 2013. Following the representations, the provincial government did not uphold the municipality's recommendations and approved the establishment of a solar farm on the airport premises in a letter dated 01 April 2014. That decision was proclaimed in the provincial gazette of 11 April 2014. The process above and the subsequent decision marked the climax of institutional tensions regarding development on Bram Fischer International Airport premises.

Continuing along the process agreements reached in 2008, in August 2014, and based upon the approved development framework, ACSA submitted an application for amendment of special use CXXI to include a wide range of additional land uses. That application was accompanied by the associated environmental impact assessment and transport impact assessment approvals. Even with the introduction of the Mangaung MPT in late 2015, a decision on that application has not yet been made in 2017 during the writing of this article.
Therefore, despite so much promise, development on the airport premises has stalled and, about 4 years after the unveiling of the municipal aerotropolis programme, the anticipated development has not materialised. The loser in this evolution of institutional arrangements is urban development, and the associated direct and indirect impacts on the broader economy of the Mangaung municipality.

\section{Conclusion}

The analysis of the case of Bram Fischer International Airport reflects the complex, dynamic, fluid and volatile nature of institutional arrangements that influence development. Given the findings of this article, it is proposed that in the planning of airports and surroundings, concerted effort should be placed on ensuring that the institutional structures are resilient, adaptive and sustainable. It is further proposed that in the context of South African planning legal framework, future studies explore ways in which the economic and political institutional arrangements could be organised towards the implementation of airport-centric developments.

\section{Acknowledgements}

The author acknowledges the constructive comments of the reviewers and editorial team.

\section{Competing interests}

The author declares that he has no financial or personal relationships which may have inappropriately influenced him in writing this article.

\section{References}

Airports Company South Africa (ACSA), 2014, Airports Company South Africa integrated report 2014, ACSA, Bedfordview.

Aoyama, Y., Murphy, J. \& Hanson, S., 2011, Key concepts in economic geography, Sage, London.

Babbie, E., 2001, The practice of social research, 9th edn., Wadsworth, Belmont, CA. Conway, M., 1993, Airport cities 21: The new global transport centers of the 21st century, Conway Data, Atlanta.

Freestone, R. \& Baker, D., 2011, 'Spatial planning models of airport-driven urban development', Journal of Planning Literature 26(3), 263-279. https://doi.org/ 10.1177/0885412211401341

Galvin, V., 2010, 'Coordinating spatial development in airport regions. Embeddedness and experimentation at Paris Orly and Amsterdam Schiphol', Aerlines 48, 1-5.

Hall, P.A. \& Taylor, R.C.R., 1996, 'Political science and the three new institutionalisms', Political Studies XLIV, 936-957. https://doi.org/10.1111/j.1467-9248.1996.tb00343.X

Hodgson, G.M., 2006, 'What are institutions?', Journal of Economic Issues 40(1), 1-25. https://doi.org/10.1080/00213624.2006.11506879

Kasarda, J.D., 2009, 'Airport cities', Urban Land 68(4), 56-60.

Kasarda, J.D. \& Lindsay, G., 2011, Aetrotropolis: The way we'll live next, Penguin Group, London.

Leedy, P.D. \& Ormrod, J.E., 2010, Practical research: Planning and design, 9th edn., Pearson, Upper Saddle River, NJ.

Leitner, H. \& Sheppard, E., 1989, 'The city as a locus of production', in R. Peet \& N. Thrift (eds.), New models in geography: The political-economy perspective, vol. II, pp. 55-83, Unwin Hyman, London.

Mangaung Municipality, 2013, Integrated development framework (2013-2014 review), Mangaung Municipality, Bloemfontein.

Martin, R., 2000, 'Institutional approaches in economic geography', in E. Sheppard \& T.J. Barnes (eds.), A companion to economic geography, pp. 77-94, Blackwell Publishers, Oxford.

Mokhele, M., 2017, 'Spatial economic evolution of the airport-centric developments of Cape Town and OR Tambo international airports in South Africa', Town and Regional Planning 70, 26-36.

Neuman, W.L., 2000, Social research method: Qualitative and quantitative approaches, 4th edn., Allyn and Bacon, Needham Heights, MA. 
North, D.C., 1990, Institutions, institutional change and economic performance, Cambridge University Press, Cambridge.

North, D.C., 1996, Economic performance through time: The limits of knowledge, viewed 05 July 2012, from http://129.3.20.41/eps/eh/papers/9612/9612004.pdf

Republic of South Africa (RSA), 1993, Airports Company Act, Act 44 of 1993, Republic of South Africa, Cape Town.

Republic of South Africa (RSA), 1996, Constitution of the Republic of South Africa, Act 108 of 1996. Statutes of the Republic of South Africa-Constitutional law viewed 22 March 2017, from http://www.gov.za/sites/www.gov.za/files/ images/a108-96.pdf

Schlaack, J., 2010, 'Defining the Airea. Evaluating urban output and forms of interaction between airport and region', in U. Knippernberger \& A. Wall (eds.), Airports in cities and regions: Research and practise, 1st International Colloquium on Airports and Spatial Development Proceedings, July 9-10, 2009, pp. 113-125, KIT Scientific Publishing, Karlsruhe.
Van Boxtel, M. \& Huys, M., 2005, 'Unravelling decision making about the future developments of Amsterdam Airport Schiphol', paper prepared for the 45th European Regional Science Association, Amsterdam, 23-27 August.

Van Wijk, M., 2007, 'Airports as cityports in the city-region', doctoral thesis, Utrecht University, Utrecht.

Van Wijk, M., 2008, 'Development of airport regions: Varieties of institutions in Schiphol and Frankfurt', Aerlines Magazine, Airports: e-zine edition 40, viewed 22 March 2017, from www.aerlines.n

Van Wyk, M., 2013, 'Solar park for Mangaung', The New Age, viewed 04 August 2013, from http://www.thenewage.co.za/printstroy.aspx?news_id= $90683 \&$ mid $=53$

Walker, A.R. \& Stevens, N.J., 2008, 'Airport city development in Australia: Land use classification and analyses', in The 10th TRAIL Congress and Knowledge Market Proceedings, Rotterdam, The Netherlands, October 14-15, viewed 12 Octobe 2017, from http://eprints.qut.edu.au/17641/1/c17641.pdf 